\title{
Bernard Vouilloux, Les Tableaux de Flaubert
}

\section{Isabella Giovinazzo}

\section{Q OpenEdition}

\section{Journals}

\section{Edizione digitale}

URL: https://journals.openedition.org/studifrancesi/41016

DOI: 10.4000/studifrancesi.41016

ISSN: 2421-5856

\section{Editore}

Rosenberg \& Sellier

\section{Edizione cartacea}

Data di pubblicazione: 1 juillet 2004

Paginazione: 214

ISSN: 0039-2944

\section{Notizia bibliografica digitale}

Isabella Giovinazzo, «Bernard Vouilloux, Les Tableaux de Flaubert», Studi Francesi [Online], 142 (XLVIII ]

I) | 2004, online dal 30 novembre 2015, consultato il 09 septembre 2021. URL: http://

journals.openedition.org/studifrancesi/41016 ; DOI: https://doi.org/10.4000/studifrancesi.41016

\section{Questo documento è stato generato automaticamente il 9 septembre 2021.}

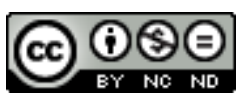

Studi Francesi è distribuita con Licenza Creative Commons Attribuzione - Non commerciale - Non opere derivate 4.0 Internazionale. 


\title{
Bernard Vouilloux, Les Tableaux de Flaubert
}

\author{
Isabella Giovinazzo
}

\section{NOTIZIA}

BERNARD VOUILLOUX, Les Tableaux de Flaubert, «Poétique» no. 135 (septembre 2003), pp.

259-287.

1 L'articolo analizza le modalità della descrizione nell'opera flaubertiana attraverso la metafora dell'opposizione tra miopia e presbiopia, utilizzata tra gli altri da Julien Gracq per distinguere gli scrittori in due categorie opposte : quelli che prediligono lo sguardo totalizzante e quelli che indugiano nella descrizione minuziosa dei dettagli, che solo lo sguardo ravvicinato può cogliere. Tale categorizzazione pone l'accento su una modalità di rappresentazione e quindi di fruizione dell'opera letteraria essenzialmente visiva, che è alla base dell'estetica realista all'interno della quale si colloca tradizionalmente Flaubert. Tuttavia, l'opera di Flaubert, che sembra privilegiare essenzialmente la descrizione «miope», è in realtà molto più complessa grazie alla ricerca dello stile, la continua giustapposizione dei quadri, la variazione della focalizzazione e l'alternanza tra oggettivo e soggettivi; l'autore passa dalla descrizione minuziosa del dettaglio alla visione d'insieme del quadro impressionista, creato della perfetta giustapposizione dei dettagli stessi, armonizzando così gli effetti delle due visioni di per sé contrastanti. 